\title{
Nutritional Status Based on Four Anthropometric Indices and Associated Factors in Children between the Ages 0-2 Years Old in a Slum of Surabaya
}

\author{
Monica Tiara Arum Kinanthi ${ }^{1 \oplus}$, Mira Irmawati ${ }^{2+(\mathbb{D}}$, Dwi Aprilawati ${ }^{3}$
}

${ }^{1}$ Faculty of Medicine, Universitas Airlangga, Surabaya, Indonesia.

2Department of Pediatrics, Faculty of Medicine, Universitas Airlangga/Dr. Soetomo General Hospital, Surabaya, Indonesia. ${ }^{3}$ Department of Public Health and Preventive Medicine, Universitas Airlangga/Dr. Soetomo General Hospital, Surabaya, Indonesia.

\section{A B S T R A C T}

Introduction: Bulak Banteng sub-district is one of the slums in Surabaya. In a study in Bulak Banteng sub-district in $2015,6.6 \%$ of children experienced malnutrition and $3 \%$ of children with Lower Red Line status. The highest number of children with Lower Red Line status was in RW 08. This study aimed to determine the nutritional status of children aged 0-2 years old in RW 08 Bulak Banteng sub-district, Surabaya, in 2018.

Methods: This study used a cross-sectional descriptive study from primary data conducted by anthropometric measurement directly on toddlers and interviews with caregivers. Assessment of four anthropometric indices includes weight-for-age, height-for-age, weight-for-height, and head circumference-for-age. A sample of 50 toddlers was taken by proportional random sampling technique.

Results: 31 children (62\%) aged 0-2 years old in RW 08 Bulak Banteng sub-district had normal growth status based on weight-for-age, height-for-age, weight-for-height, and head circumference-for-age. The remaining growth status of 27 children (54\%) is as follows. Based on the weight-for-age index, a child (2\%) was severely underweight, and 7 children (14\%) were underweight. Based on the height-for-age index, 4 children $(8 \%)$ were severely stunted, and 7 children $(14 \%)$ were stunted. Based on the index of weight-for-height, a child (2\%) was severely wasted, and 5 children (10\%) were wasted. Based on the index of head circumference-for-age, there were 1 child (2\%) microcephaly and 3 children (6\%) macrocephaly.

Conclusion: This study found that many children aged 0-2 years old in the slum area of RW 08 Bulak Banteng sub-district in Surabaya experienced growth delays.

\footnotetext{
*Correspondence: irmawatimira@gmail.com
}

JUXTA: Jurnal IImiah Mahasiswa Kedokteran Universitas Airlangga

p-ISSN: 1907-3623; e-ISSN: 2684-9453

DOI: $10.20473 /$ juxta.V12I22021.84-89

Open access under Creative Commons Attribution-ShareAlike 4.0 International License (CC-BY-SA)

\section{ARTICLE INFO}

Article history:

Received 2 June 2021

Received in revised form 10 July 2021

Accepted 7 August 2021

Available online 31 August 2021

\section{Keywords:}

Child growth,

Nutritional status,

Slums,

Undernourished,

Undernutrition. 


\section{Introduction}

The process of growth and development is the result of the interaction of genetic and environmental factors. Genetic factors are related to genes originating from the father and mother, while environmental factors include biological, physical, psychological, and socioeconomic status.

The first 1000 days period is often called the window of opportunities or golden period is that from fetus to 2 years old child, the growth process occurs very quickly and does not occur in other age groups. According to the Minister of Health, the term 1000 First Day of Life was introduced in 2010 since the launch of the Scaling-up Nutrition Movement at the global level. Failure to thrive in the 1000 First Days of Life period will not only lead to disruption of physical growth but also cause metabolic disorders, especially disorders of metabolism of fats, proteins, and carbohydrates, which can eventually trigger the emergence of non-communicable diseases in adulthood. ${ }^{1}$

Child growth is influenced by many factors, one of which is parenting, which is closely related to the level of education and knowledge. The low level of parents' education is the risk of child growth delay because it is related to knowledge about health and the ability to provide stimulation. ${ }^{2}$ It was found from a case-control study of 250 children aged $<36$ months old in Bangladesh that maternal education had a significant relationship with the incidence of malnutrition. ${ }^{3}$ The prevalence of stunting in children $>42$ months old in the slums of Nairobi (Africa) is close to $40 \%$. In this study, it was found that maternal education was an important predictor of stunted in children. ${ }^{4}$

Environmental factors, infectious diseases, inadequate eating patterns, and poverty appear to be far more important than genetic predisposition as a determinant of malnutrition in children. ${ }^{5}$ Low-income families have a greater tendency to have children who grow late. This may be related to the ability of families to provide balanced nutritious food for their children. ${ }^{6} \mathrm{~A}$ study shows that low household income is a risk factor that contributes to children's nutritional problems in the slums of Nagpur, India. ${ }^{7}$

From Nutritional Status Monitoring in Indonesia in 2017, the following results are obtained. Based on the weight-for-age index, $3.8 \%$ of children under five were severely underweight, and $14.0 \%$ of children under five were underweight. Based on the height-for-age index, $9.8 \%$ of toddlers were severely stunted, and $19.8 \%$ were stunted. Based on the weight-for-height index, $2.8 \%$ of children under five were severely wasted, and $6.7 \%$ were wasted. The results of the comparison of nutritional status problems in 2016 and 2017 showed that there was an increase in the prevalence of short and fat and a decrease in thin problems. ${ }^{8}$

Based on the population recap report of Bulak Banteng sub-district as of February 2016, the total population was 25,691 . The majority of the population is migrated from
Madura. The average education of the residents of Bulak Banteng sub-district is relatively low. Their work base is as factory workers, construction workers, or craftsmen. Mostly, mothers only become housewives, and their total income comes only from their father. The condition of the house coincides and is far from the standard of a healthy home. ${ }^{9}$ Occupancy density and building density are high since one house is inhabited by several families. ${ }^{10}$ In addition, sanitation is poor, and some latrines still use barracks on the river. ${ }^{11}$

In December 2015, 92 children under the Red Line and 203 children were malnutrition from a total of 3060 under-fives in Bulak Banteng sub-district. The highest number of under the Red-Line children is in RW 08, known to be a slum. So far, many programs have been routinely held by Puskesmas, such as counseling, monitoring, and supplementary feeding. However, these programs have not significantly affected the problem of nutritional status of toddlers in Bulak Banteng sub-district. ${ }^{9}$ Therefore, this study aims to determine the nutritional status of children aged 0-2 years old in RW 08 Bulak Banteng sub-district, Surabaya, in 2018.

\section{Methods}

This research was a cross-sectional descriptive study. The variables were the age of the child, gender of the child, gestational age, breastfeeding, vaccination status, child growth, maternal age, caregiver's educational level, parental occupation, and family income. The population was all children aged 0-2 years old in the slums of RW 08 Bulak Banteng sub-district, Surabaya. A sample of 50 toddlers was obtained using proportional random sampling technique based on inclusion criteria that were mothers and children aged 0-2 years old who registered as members in 7 Posyandu in RW 08. The data obtained were analyzed and presented in the form of tables.

\section{Results}

Table 1. The characteristics of children aged 0-2 years old

\begin{tabular}{lc}
\hline \multicolumn{1}{c}{ Variable } & $\mathbf{n}(\%)$ \\
\hline Gender & $34(68 \%)$ \\
Male & $16(32 \%)$ \\
Female & \\
Age & $23(46 \%)$ \\
$0-12$ & $27(54 \%)$ \\
$12-24$ & \\
Gestational age & $9(18 \%)$ \\
$\quad$ Preterm & $39(78 \%)$ \\
$\quad$ Aterm & $2(4 \%)$ \\
Post term & \\
Exclusive breastfeeding & $39(78 \%)$ \\
$\quad$ Yes & $11(22 \%)$ \\
$\quad$ No & \\
Vaccination status & $36(72 \%)$ \\
$\quad$ Complete & $14(28 \%)$ \\
Incomplete &
\end{tabular}


Results revealed 50 children aged $0-2$ years old; most of the children were male $(24 \%)$, the majority of age was $12-24$ years old $(54 \%)$, mostly were born aterm $(78 \%), 39$ children $(78 \%)$ received exclusive breastfeeding, and the majority of vaccination status was in complete ( $72 \%$ ) (Table 1).

Table 2. The characteristics of parents

\begin{tabular}{|c|c|}
\hline Variable & n (\%) \\
\hline \multicolumn{2}{|c|}{ Caregiver's relationship to child } \\
\hline Mother & $43(86 \%)$ \\
\hline Other & $7(14 \%)$ \\
\hline \multicolumn{2}{|l|}{ Gender of the caregiver } \\
\hline Male & $0(0 \%)$ \\
\hline Female & 100 (100\%) \\
\hline \multicolumn{2}{|l|}{ Maternal age } \\
\hline$<20$ & $6(12 \%)$ \\
\hline $20-24$ & $9(18 \%)$ \\
\hline $25-29$ & $18(36 \%)$ \\
\hline 30-34 & $8(16 \%)$ \\
\hline$\geq 35$ & $9(18 \%)$ \\
\hline \multicolumn{2}{|c|}{ Caregiver's educational level } \\
\hline None & $3(6 \%)$ \\
\hline Primary & $15(30 \%)$ \\
\hline Secondary & $12(24 \%)$ \\
\hline High/Higher & $20(40 \%)$ \\
\hline \multicolumn{2}{|l|}{ Occupation of mothers } \\
\hline Private employees & $4(8 \%)$ \\
\hline Labourer & $1(2 \%)$ \\
\hline Entrepreneur & $4(8 \%)$ \\
\hline Housewife & $341(82 \%)$ \\
\hline \multicolumn{2}{|l|}{ Occupation of fathers } \\
\hline Private employees & $38(76 \%)$ \\
\hline Labourer & $9(18 \%)$ \\
\hline Entrepreneur & $3(6 \%)$ \\
\hline \multicolumn{2}{|l|}{ Family income } \\
\hline$<$ Rp.3.500.000,00 & $27(54 \%)$ \\
\hline$\geq$ Rp.3.500.000,00 & $23(46 \%)$ \\
\hline
\end{tabular}

Results revealed that most children aged $0-2$ years old were cared for by their biological mothers (86\%). All caregivers were female (100\%). The highest maternal age was at the age of $25-29$ years old $(36 \%)$. The majority of mothers were housewives (82\%). Most of the father's occupations were private employees $(76 \%)$. The low family income was $54 \%$ (Table 2 ).

Table 3. Distribution of growth rates of children aged 0-2 years old

\begin{tabular}{lc}
\hline Index and Category & $\mathbf{n ~ ( \% )}$ \\
\hline Weight-for-age & $1(2 \%)$ \\
Severely underweight & $7(14 \%)$ \\
Underweight & $42(84 \%)$ \\
Normal & $0(0 \%)$ \\
Overweight & \\
Height-for-age & $4(8 \%)$ \\
Severely stunted & $7(14 \%)$ \\
Stunted & $37(74 \%)$ \\
Normal & $2(4 \%)$ \\
Tall & \\
Weight-for-height & $1(2 \%)$ \\
Severely wasted & $5(10 \%)$ \\
Wasted & $44(88 \%)$ \\
Normal & $0(0 \%)$ \\
Overweight/obese & \\
Head circumference-for-age & $1(2 \%)$ \\
Microcephaly & $46(92 \%)$ \\
Normal &
\end{tabular}

Macrocephaly

$3(6 \%)$

Results revealed that 42 children had good nutritional status based on the weight-for-age index, while seven children were underweight. Based on the height-for-age index, 37 children with normal nutritional status and 7 children were stunted. Based on the weight-for-height index, there were 44 children with normal nutritional status and 5 wasted children. Based on the head circumferencefor-age index, $92 \%$ of children had normal head circumference according to their age (Table 3 ).

\section{Discussion}

Preterm birth is a significant factor causing stunting. ${ }^{12}$ The growth of 1-year-old children found an increased risk of growth disorders associated with premature occurrence, but this was also triggered by the Apgar score (asphyxia) and the presence of labor complications. ${ }^{13}$

The prevalence of preterm cerebral leads to stunted and wasted children, high in South Asia and Sub-Saharan Africa but low in Oceania and Central Asia. Based on the analysis of studies in toddlers 12-60 months old, the incidence of underweight, wasted, and stunted was associated with low birth weight (LBW) and prematurity. However, on long-term growth in children, the relationship between LBW and stunted events is more meaningful than prematurity. ${ }^{14}$

Another case with research in Pelotas, South Brazil, is that the growth of children born preterm is faster than children born at term, but children with a history of preterm have a high risk of experiencing thin and stunted in the first two years of life. ${ }^{15}$ This may occur because of the provision of good nutrition by parents to their children due to anxiety and responsiveness in response to the occurrence of preterm birth. Therefore, optimal nutrition is the key to growth, metabolism, and immunity in premature infants with LBW, as well as reducing the risk of adult morbidity. ${ }^{16}$

According to nutritional status, the results of the growth assessment found that infants who were given exclusive breastfeeding had more normal growth than infants who were given non-exclusive breastfeeding. The results of this study are comparable with the research conducted by Budi Cahyadi in the Linggajaya sub-district of Tasikmalaya City in 2012 that the relationship of breastfeeding was not significant with the growth of infants ( $p$ value $=0.153$ ). The relationship of breastfeeding is not significant with the growth of the baby probably due to the quantity and quality of breast milk given by the mother is still lacking and does not meet the needs of the baby so that the weight gain and body length of the baby is not optimal. ${ }^{17}$

Durmus, et al. (2011) concluded that duration of breastfeeding less than 6 months old and formula feeding under 6 months of age was associated with increased growth (height, weight, and BMI in infants aged 3-6 months old) but were not at risk for overweight and obesity until 3 years old. ${ }^{18}$ Another study with the ANCOVA statistical test showed a relationship between exclusive breastfeeding 
and stunted and underweight, but there was no significant association with the incidence of wasted.

Aceh is an area with the most extensive prevalence of stunted babies in Indonesia. Acehnese people already have awareness about breastfeeding, but the problem is the lack of knowledge about exclusive breastfeeding. ${ }^{19}$ Anggraini (2017) found that infants under 6 months old have been given bananas and honey, even though newborn babies up to the age of 6 months old should only be given breast milk. ${ }^{19}$

In the interpretation of weight-for-age index and weight-for-height, the number of underweight and wasted children is more significant in children who do not receive complete immunization. However, in the height-for-age index and head circumference-for-age, children with complete immunization dominated the number of stunted children and abnormal head circumference.

In an observational study on Ahmedad, there was a significant association between a history of incomplete immunization and the incidence of diarrhea and malnutrition. ${ }^{20}$ This research is supported by a study in Tanzania that there is a significant relationship between the incidence of malnutrition in children and incomplete immunization $(p$ value $=0.042) .^{21}$

Maternal age $<20$ years old or $\geq 35$ years old is at high risk for childbirth. In women aged $\geq 35$ years old, there is a significant tendency for pre-eclampsia and hypertension to occur, which can cause bleeding and labor too early. ${ }^{22}$ Pregnancy under the age of 20 years old can cause many problems because it can affect organs such as the uterus. Even babies can be premature and have less birth weight. This is because a pregnant woman cannot provide a good supply of food from the body to the fetus in the uterus. ${ }^{23}$ Pregnancy at the age of $<20$ years old will cause fear of pregnancy and childbirth. This is because the mother may not be ready to have children and the reproductive organs of the mother are not ready to get pregnant.

Children with young mothers in the middle to lowerincome countries (Brazil, Guatemala, India, Philippines, South Africa) who are born with complications need good nutrition to prevent disruption of growth early on. Research also shows that older mothers are better at providing nutrition to their children. In addition, extreme maternal age is also associated with impaired glucose metabolism. Mothers born at a young age increase the risk of LBW and prematurity, stunted in child or adult, and higher fasting glucose concentrations as adults. ${ }^{24}$

Parental education is one factor that influences child growth because, with good education, parents can receive information from outside, excellent ways of caring for children, maintaining health, and educating them. ${ }^{25}$ Mothers with higher levels of education will be easier to receive information from outside, compared to mothers who have lower levels of education. ${ }^{26}$

Research in Nigeria revealed that the prevalence of underweight and stunted was high in children from families with high economic status who usually come from parents highly educated. It can happen because parents are too focused on their children's education, so they pay less attention to the nutrients in the food that their children get. ${ }^{27}$

Incidence of stunting in Indonesia are significantly associated with children with low educated mothers, especially in children aged 0-23 months old. However, stunting events are also influenced by poor home environment sanitation, including the unavailability of latrines and poor drinking water treatment. ${ }^{28}$ Mothers with low education levels do not always have toddlers with more growth problems than mothers with higher levels of education. A high level of mother's knowledge does not guarantee having a toddler with normal nutritional status. ${ }^{26}$

A study in Southern Ethiopia concluded that maternal knowledge and education of health professionals were significantly related to monitoring growth in children. Mothers with low education levels tend to have low levels of knowledge. Mothers with low levels of knowledge tend to have poor parenting. ${ }^{29}$ The majority of school-age children in Nkontompo (Ghana) have good nutritional status because parents have good knowledge about effective practices in optimizing the nutritional status of their children. The leading practices include exclusive breastfeeding, complete immunization, weight monitoring, and supplementary feeding. ${ }^{30}$

It was found that there was no statistically significant relationship between the profession of mother and child growth. Mothers who work or housewives can have the same awareness to fulfill their children's nutritional needs, which ultimately can affect growth. ${ }^{31}$ Even though working mothers do not have much time with their children, they can pay attention to their feeding.

A study stated that there is no relationship between maternal employment status and stunted. ${ }^{32}$ It is also known that mothers' employment status positively affects the growth of children by increasing family income, providing healthy nutritious food, good sanitation, and optimal health care. However, the work status of the mother is related to overweight in children. This is because mothers who work outside the home only have a short time for their children to prepare food and tend to choose fast foods high in calories and rarely provide balanced nutritious food.

According to UNICEF, one of the things that underlie the occurrence of malnutrition in children under five is socio-economic factors. Socio-economic factors influence the provision of resources for food availability, care, and child health services in the family. Socio-economics includes family income, education status, and economic activities of the head of the household. It has a role in food security, basic sanitation, utilization of health services, and parenting. ${ }^{33}$

\section{Conclusion}

This study revealed that most children aged $0-2$ years old in RW 08 Bulak Banteng sub-district experienced normal growth. However, many children experienced growth delays based on the weight-for-age, height-for-age, weight-for-height, or head circumference-for-age indices. 


\section{CONFLICT OF INTEREST}

The author stated there is no conflict of interest in this study.

\section{REFERENCES}

1. Indonesia KKR. Penuhi Kebutuhan Gizi pada 1000 Hari Pertama Kehidupan. Jakarta, 2012.

2. Imdad A, Yakoob MY, Bhutta ZA. Impact of Maternal Education about Complementary Feeding and Provision of Complementary Foods on Child Growth in Developing Countries. BMC Public Health 2011; 11 Suppl 3: S25.

3. Rayhan MI, Khan M. Factors Causing Malnutrition among Under Five Children in Bangladesh. Pakistan J Nutr; 5. Epub ahead of print 1 June 2006. DOI: 10.3923/pjn.2006.558.562.

4. Abuya BA, Ciera J, Kimani-Murage E. Effect of Mother's Education on Child's Nutritional Status in the Slums of Nairobi. BMC Pediatr 2012; 12: 80.

5. Sengupta $P$, Philip N, Benjamin A. Epidemiological Correlates of Under-Nutrition in Under-5 Years Children in an Urban Slum of Ludhiana. Health Popul Perspect Issues 2010; 33: 1-9.

6. Srivastava A, Mahmood SE, Srivastava PM, et al. Nutritional Status of School-Age Children - A Scenario of Urban Slums in India. Arch Public Health 2012; 70: 8.

7. Vinod N, Swarnakanta L, Smita P, et al. Nutritional Status and Dietary Pattern of under Five Children in Urban Slum Area. Nat J Community Med; 2.

8. Indonesia KKR. Hasil Pemantauan Status Gizi (PSG) Tahun 2017. Jakarta, 2018

9. Muchlasin. Gambaran Kehidupan di Kampung Bulak Banteng. Universitas Islam Negeri Surabaya, 2016.

10. Kusumastuti. Kajian Prasarana dan Sarana Lingkungan Permukiman Kumuh di Bulak Banteng Surabaya. Surabaya, 2005.

11. Andini I. Sikap dan Peran Pemerintah Kota Surabaya Terhadap Perbaikan Daerah Kumuh di Kelurahan Tanah Kalikedinding Kota Surabaya. Kebijak dan Manaj Publik 2013; 1: 36-47.

12. Zhang J, Shi J, Himes JH, et al. Undernutrition Status of Children under 5 years in Chinese Rural Areas Data from the National Rural Children Growth Standard Survey, 2006. Asia Pac J Clin Nutr 2011; 20: 584-592.

13. Santoso AB. Hubungan antara Kelahiran Prematur dengan Tumbuh Kembang Anak pada Usia 1 Tahun. Universitas Diponegoro, 2003.

14. Christian $P$, Lee SE, Donahue Angel $M$, et al. Risk of Childhood Undernutrition Related to Small-forGestational Age and Preterm Birth in Low- and Middle-Income Countries. Int J Epidemiol 2013; 42: $1340-1355$

15. Santos IS, Matijasevich A, Domingues MR, et al. Late Preterm Birth is a Risk Factor for Growth Faltering in Early Childhood: A Cohort Study. BMC Pediatr 2009; 9: 71.

16. Kumar RK, Singhal A, Vaidya U, et al. Optimizing Nutrition in Preterm Low Birth Weight InfantsConsensus Summary. Front Nutr 2017; 4: 20.

17. Fitri D, Chundrayetti E, Semiarty R. Hubungan Pemberian ASI dengan Tumbuh Kembang Bayi Umur 6 Bulan di Puskesmas Nanggalo. J Kesehat Andalas; 3. Epub ahead of print 1 May 2014. DOI: 10.25077/jka.v3i2.51.
18. Durmuş B, van Rossem L, Duijts L, et al. BreastFeeding and Growth in Children until the Age of 3 Years: the Generation R Study. Br J Nutr 2011; 105: 1704-1711.

19. Anggraini D. The Effect of Breast Milk toward Children's Growth: A Systematic Review. LIFE Int J Heal LifeSciences; 3. Epub ahead of print 1 January 2017. DOI: 10.20319/lijhls.2017.31.1428.

20. Vora HD, Reddy D V., Prajapati VJ, et al. Study of Feeding Practices and Vaccination Status Effect on Growth and Illness in Children of 6months to 2years. Natl J Community Med 2017; 8: 385-389.

21. Ahmed MM, Hokororo A, Kidenya BR, et al. Prevalence of Undernutrition and Risk Factors of Severe Undernutrition among Children Admitted to Bugando Medical Centre in Mwanza, Tanzania. BMC Nutr 2016; 2: 49.

22. Kristiyanasari W. Gizi Ibu Hamil. Yogyakarta: Nuha Medika, 2010.

23. Marmi, Rahardjo K. Asuhan Neonatus, Bayi, Balita, dan Anak Prasekolah. Yogyakarta: Pustaka Pelajar, 2012.

24. Fall CHD, Sachdev HS, Osmond C, et al. Association between Maternal Age at Childbirth and Child and Adult Outcomes in the Offspring: A Prospective Study in Five Low-Income and Middle-Income Countries (COHORTS Collaboration). Lancet Glob Heal 2015; 3: e366-77.

25. Hartawan I, Windiani IGAT, Soetjiningsih S. Karakteristik Tumbuh Kembang Anak di Tempat Penitipan Anak Werdhi Kumara 1, Kodya Denpasar. Sari Pediatr 2016; 10: 134.

26. Ni'mah C, Muniroh L. Hubungan Tingkat Pendidikan, Tingkat Pengetahuan dan Pola Asuh lbu dengan Wasting dan Stunting pada Balita Keluarga Miskin Media Gizi Indones 2015; 10: 84-90.

27. D.C O, Ikpeme E, Ekanem U. Prevalence of Stunting, Underweight and Obesity in School Aged Children in Uyo, Nigeria. Pakistan J Nutr; 9. Epub ahead of print 1 May 2010. DOI: 10.3923/pjn.2010.459.466.

28. Torlesse $\mathrm{H}$, Cronin AA, Sebayang SK, et al. Determinants of Stunting in Indonesian children: Evidence from a Cross-Sectional Survey Indicate a Prominent Role for the Water, Sanitation and Hygiene Sector in Stunting Reduction. BMC Public Health 2016; 16: 669.

29. Daniel B, Tesfaye N, Mekonin E, et al. Knowledge and Attitude on Growth Monitoring and its Associated Factors among Mothers/Guardians of Children Less than Two Years in Areka Town, Southern Ethiopia, 2017. J Nutr Disord Ther; 07. Epub ahead of print 1 January 2017. DOI: 10.4172/2161. 0509.1000216.

30. Sethi D, Sehgal S, Mehta D. Influence of SocioEconomic Factors on Nutritional Status of Rural School Going Children in Haryana. Ann Biol 2014; 30: 412-416.

31. Putri DFTP, Kusbaryanto -. Perbedaan Hubungan antara lbu Bekerja dan lbu Rumah Tangga terhadap Tumbuh Kembang Anak Usia 2-5 Tahun. Mutiara Med J Kedokt dan Kesehatan; Vol 12, No 3. Epub ahead of print 2016. DOI: 10.18196/mmjkk.v12i3.1032.

32. Géa-Horta T, Felisbino-Mendes MS, Ortiz RJF, et al. Association between Maternal Socioeconomic Factors and Nutritional Outcomes in Children Under 5 Years of Age. J Pediatr (Rio J) 2016; 92: 574-580. 
33. Martha H. Faktor Sosial Ekonomi Gangguan

Pertumbuhan Anak 0-59 Bulan Riskesdas Tahun 2010. Universitas Indonesia, 2014. 